1. MBBS, M.Phil (Histopathology) Assistant Professor

Department of Pathology

Islam Medical and Dental College, Sialkot.

2. MBBS, M.Phil (Histopathology) Professor

Department of Pathology Hazrat Bari Imam Sarkar Medical College, Islamabad.

3. MBBS, M.Phil (Histopathology) Senior Demonstrator Department of Pathology Aziz Fatimah Medical College, Faisalabad.

4. MBBS, M.Phil (Histopathology) Demonstrator

Shifa College of Medicine, Islamabad.

5. MBBS, M.Phil (Histopathology) Consultant Pathologist Tehsil Heaquarter Hospital,Kahuta.

6. MBBS, PGR MD (Histopathology) Pakistan Institute of Medical Sciences, Islamabad.

Correspondence Address:

Dr. Saira Javeed

Department of Pathology

Islam Medical and Dental College,

Sialkot.

sairajaveed29@gmail.com

Article received on:

18/02/2019

Accepted for publication:

09/07/2019

Received after proof reading: $28 / 08 / 2019$

\section{IMMUNOHISTOCHEMICAL EXPRESSION OF P53 IN BASAL CELL CARCINOMA OF SKIN.}

\begin{abstract}
Saira Javeed ${ }^{1}$, Ashok Kumar ${ }^{2}$, Iram Asrar ${ }^{3}$, Rabiya Fawad ${ }^{4}$, Marrium Waqar $^{5}$, Nosheen Nabi ${ }^{6}$
ABSTRACT... Objectives: To evaluate the immunohistochemical expression of p53 in basal cell carcinoma of skin. Study Design: It was cross sectional study. Setting: Pathology department of Pakistan Institute of Medical Sciences Hospital, Shaheed Zulfiqar Ali Bhutto Medical University, Islamabad, Pakistan. Period: Six months from July 2015 to January 2016 after approval from the Hospital Ethical Committee. Material and Methods: In a descriptive background, 50 cases were involved in the study. Cases were selected by non-probability consecutive sampling technique. Patients of all age group (Males and Females), diagnosed as basal cell carcinoma of skin by Hematoxylin \& Eosin were included in study. Other epithelial tumors of skin, appendageal tumors and metastatic tumors were excluded. Cases were evaluated for expression of tumor suppressor protein-p53 by immunohistochemical technique applied on formalin-fixed paraffinembedded blocks. Results: Out of 50 cases, majority of patients were found to be male. Ratio of male to female was 2.6:1. Age range of patient was found between 21-98 years. Mainstream of the patients were between 41-60 years. Nose was found to be frequently involved site 28 (56\%) cases. p53 expression was seen in 42 (84\%) cases while in $8(16 \%)$ cases p53 expression was not seen. Conclusion: It was found that p53 expression rate is very high in basal cell carcinoma of skin. This high expression of p53 immunoreactivity was explained in terms of its pathogenetic role and mutation in basal cell carcinoma.
\end{abstract}

Key words: Basal Cell Carcinoma, Immunohistochemistry, Tumor Suppressor Protein p53.

Article Citation: Javeed S, Kumar A, Asrar I, Fawad R, Waqar M, Nabi N. Immunohistochemical expression of P53 in basal cell carcinoma of skin. Professional Med J 2019; 26(9):1500-1505. DOI: 10.29309/TPMJ/2019.26.09.3555

\section{INTRODUCTION}

Basal cell carcinoma (BCC) is one of the most common primary skin tumor. In Pakistan, incidence of the skin cancer is low. In Ayub Medical College, Abbottabad, skin cancer constitutes about $1.04 \%$ of all neoplasms reported over a period of nine years. ${ }^{1}$

Basal cell carcinoma of skin arises from basal layer of epidermis. It commonly occurs in elderly people. ${ }^{2}$ BCC usually arises on sun-exposed areas, most frequently the nose. Mostly, it represents as nodular ulcerative abrasion or asymptomatic nodule and contains telangiectatic vessels. They are slow growing tumors that can cause huge local destruction and disfigurement but rarely metastasize. ${ }^{3}$ After primary treatment, central area of the face e.g. eyelids, nasolabial fold, periorbital region, nose-cheek angle, postauricular area, ear canal, pinna, forehead and scalp are common sites for recurrence. Microscopically, Tumor is composed of basaloid cells having elongated hyperchromatic nuclei with peripheral palisading and scanty cytoplasm. Clefting around tumor, mucinious and myxoid stroma also seen. These features help to differentiate BCC from other basaloid tumors. BCC has different histological patterns that include nodular, micronodular, solid, superficial, adenoid, keratotic, cystic, pigmented, infiltrating and sclerosing. ${ }^{3}$ Superficial and nodular types have comparatively less malignant behaviour. While aggressive subtypes include micronodular, infiltrating, morphoeic or sclerosing and BCC with squamous differentiation. Aggressive BCC subtypes have higher rates of recurrence and excision margin involvement. Histopathological sub typing of BCC is important for patient 
management. ${ }^{4}$ About $90 \%$ of nodular BCC arise in head and neck. ${ }^{5}$

There are many factors involved in the pathogenesis of BCC that includes genetics and environmental factors. Ultraviolet radiations (UVR) are most common environmental risk factors that contribute in development of the skin cancer. ${ }^{6}$ Other factors include ionizing radiations, chemical carcinogens and papilloma virus infection. Depletion of ozone layer causes ultraviolet radiations to reach the earth. Ultraviolet radiation exposures are related in about 93\% cases of the skin cancers. ${ }^{7}$ Unawareness about the disease and late diagnosis contributes in high mortality and morbidity. Treatment of the skin cancer depends upon various factors like type of tumor, site of tumor, size of lesion and the depth of penetration.

The p53 is the most commonly mutated gene in sun-exposed skin and cancers in the skin. ${ }^{8}$ p53 is a tumor suppressor gene that helps in cell cycle control. p53 protein perform this function by inducing cell cycle arrest, programmed cell death (Apoptosis) and DNA repair. Upon damage p53 gene binds with DNA and causes cell cycle arrest in G1 phase of cell cycle and induces DNA repairing. However, mutated p53 gene disrupt the cell cycle in form of uncontrolled growth and inhibit the repair of damaged DNA. ${ }^{9}$ Inactivation or overexpression of p53 is an indicator of mutation of p53 gene. ${ }^{8}$

In UV-induced skin tumors like BCC, the importance of p53 mutation is well known. The p53 expression can be stimulated by UV light, which cause the DNA damage. Also, overexpression of p53 protein is an age related process. These findings explain the role of p53 protein expression in cutaneous malignancies. ${ }^{10}$ Immunohistochemical analysis of p53 expression is used as a marker for mutational analysis in case of basal cell carcinoma of skin. ${ }^{11}$

The rationale of this study was to see the immunohistochemical expression of p53 in basal cell carcinoma of skin and its various subtypes. Overexpression of p53 practically helps as an important tool for prediction of tumor progression. This also helps to design a more rational treatment protocol.

\section{MATERIALS AND METHODS}

The cross sectional study was carried out in Pathology department in collaboration with Dermatology and Plastic surgery department, Pakistan Institute of Medical Sciences (PIMS) Hospital, Shaheed Zulfiqar Ali Bhutto Medical University (SZABMU), Islamabad, Pakistan. The duration of study was six months from July 2015 to January 2016 after approval from ethical committee of hospital. Male and female patients of all age groups; diagnosed with basal cell carcinoma of the skin on routine Hematoxylin and Eosin (H\&E) were included. Cases of metastatic carcinoma, cases of the skin appendageal cancers and epithelial skin cancers other than $\mathrm{BCC}$ were excluded. After applying IHC technique, prepared slides were examined with the help of light microscope. A positive as well as negative control was used in each case. Brown staining in the nuclei of tumor cells was considered positive staining. The nuclear reactivity was classified into two categories either positive or negative. When there was no nuclear reactivity it was considered negative. Heterogeneous nuclear reactivity ranging between $1-50 \%$ of tumor cells and homogenous nuclear staining between 50 $100 \%$ of tumor cells was considered positive. The percentage of positive staining was calculated in 200 tumor cells nuclei. Quotients (positive tumor cells/total counted tumor cells) calculated as percentage was smoothed to the close figure. Percentage of positive cells was documented. The samples were classified according to the staining marked below:

1. Score 1: No staining (Negative)

2. Score 2: $1-4 \%$

3. Score 3: $5-50 \%$

4. Score 4: $51-100 \%$

Using the statistical package for social sciences IBM SPSS software, (SPSS Version 22) statistical analysis was performed. The numerical variable like age was analyzed as mean and standard deviation. The categorical variable like gender, site of specimen, histological subtype, p53 
expression and IHC score were calculated as frequency and percentages.

\section{RESULTS}

A total number of 50 cases were included in the study. Of these 50 cases, $36(72 \%)$ were male while females were $14(28 \%)$. The male to female ratio was 2.6:1. Minimum age of patient included in our study was 21 years while maximum age of patient was found to be 98 years. The mean age of patients with standard deviation was $52.92 \pm 16.95$ years. The age range for male patients was between 21-98 years and for females was between 38-86 years. Frequency of age distribution in different age group is shown in Table-l.

The most common tumor site was nose 28 (56\%) cases, followed by forehead 5 (10\%) cases, cheek $5(10 \%)$ cases, lip constituted 4 (8\%) cases while $3(6 \%)$ cases were from left eye margin. There was one each case from scalp (2\%), right eyebrow (2\%), heel (2\%), nasolabial fold (2\%) and chin $(2 \%)$.

Of all the cases of BCC, 42 (84\%) cases showed positivity for p53 expression. In remaining 8 (16\%) cases p53 expression was not seen.

Frequency of p53 expression in Basal cell carcinoma according to iummohistochemistry score mentioned in material and methodology is shown in Table-II.

Cases of basal cell carcinoma were classified into various variants of $\mathrm{BCC}$ and $\mathrm{p} 53$ expression was noted as shown in Table-III.

\begin{tabular}{|l|c|c|}
\hline \multicolumn{1}{|c|}{ Age Distribution } & Frequency & Percentage \\
\hline $21-40$ years & 10 & $20 \%$ \\
\hline $41-60$ years & 29 & $58 \%$ \\
\hline $61-80$ years & 6 & $12 \%$ \\
\hline $81-100$ years & 5 & $10 \%$ \\
\hline Total & 50 & $100 \%$ \\
\hline
\end{tabular}

Table-I. Frequency of age distribution $(n=50)$

\begin{tabular}{|c|c|c|c|}
\hline Negative & \multicolumn{3}{|c|}{ Positive } \\
\hline $\begin{array}{c}\text { Score 1 } \\
(\mathbf{0} \%)\end{array}$ & $\begin{array}{c}\text { Score 2 } \\
(\mathbf{1 - 4 \% )}\end{array}$ & $\begin{array}{c}\text { Score 3 } \\
\mathbf{( 5 - 5 0 \% )}\end{array}$ & $\begin{array}{c}\text { Score 4 } \\
\mathbf{( 5 1 - 1 0 0 \% )}\end{array}$ \\
\hline $8(16 \%)$ & $4(8 \%)$ & $11(22 \%)$ & $27(54 \%)$ \\
\hline & $\begin{array}{c}\text { Table-II. Frequency distribution of p53 in BCC } \\
\text { according to IHC score (n=50) }\end{array}$ \\
\hline
\end{tabular}

\begin{tabular}{|l|c|c|}
\hline $\begin{array}{c}\text { Histological } \\
\text { Subtype }\end{array}$ & No. of Cases & $\begin{array}{c}\text { p53 Expression } \\
\text { Present }\end{array}$ \\
\hline Superficial & $27(54 \%)$ & $23(46 \%)$ \\
\hline Infiltrative & $9(18 \%)$ & $7(14 \%)$ \\
\hline Basosquamoid & $7(14 \%)$ & $5(10 \%)$ \\
\hline Nodular & $5(10 \%)$ & $5(10 \%)$ \\
\hline sclerosing & $1(2 \%)$ & $1(2 \%)$ \\
\hline Micronodular & $1(2 \%)$ & $1(2 \%)$ \\
\hline Total & $50(100 \%)$ & $42(84 \%)$ \\
\hline $\begin{array}{c}\text { Table-III. Frequency distribution of cases with } \\
\text { histological subtype and p53 expression in various } \\
\text { subtypes of BCC (n=50) }\end{array}$ \\
\hline \multicolumn{2}{|c|}{} \\
\hline
\end{tabular}

\section{DISCUSSION}

Basal cell carcinoma, the most frequently occurring skin tumor involves multiple factor in its pathogenesis and is disease of elderly people. BCC arise from basal layer of epidermis. Malignant potential frequently increases because of mutation of p53 tumor suppressor gene. Many studies internationally have reported immunohistochemical expression of p53 in BCC Due to lack of studies about role of p53 in basal cell carcinoma in Pakistan, we have examined p53 expression and its intensity immunohistochemically and has related it with age of patient, gender, anatomical site of tumor and its various histological subtypes.

According to our study results, $72 \%$ of male patients and only $28 \%$ females were diagnosed with BCC. Male to female ratio was 2.6:1. This ratio showed male preponderance mainly because males were outdoor workers or field workers and had more sun exposure which is a common factor in pathogenesis of BCC. On the other hand, in our society females are mostly house workers and have less exposure to sun light. ${ }^{12}$ This data was found similar to that provided by Ahmed et al who also found that skin cancers are more prevalent in males in Pakistan. ${ }^{1}$ Similar 
results were concluded by Soomro FR et al in his study of cutaneous malignant tumors at Larkana. He correlated his results of male predominance with occupation. ${ }^{12}$

In our study, age range for BCC was found between 21-98 years. Maximum numbers of patients were seen between 41-60 years of age. These results are comparable with the results of Paracha MM et al who also found that basal cell carcinomas are common between $4^{\text {th }}$ to $8^{\text {th }}$ decades. ${ }^{13}$ In another study by Chinem VP and Miot HA, it was reported that basal cell carcinoma usually arises in elderly people but younger than age of onset in squamous cell carcinoma. ${ }^{14}$ This phenomenon of development of cutaneous malignancies more in adults and elderly people is explained in terms of role of chronic sun exposure. Acute and intermittent exposure to ultraviolet radiation has little role while unprotected, prolonged and chronic exposure results in development of skin malignancies at late age.

In present study, face predominantly nose was found to be the most common site for BCC. This is comparable with results concluded by Paracha MM et al and Laishram RS et al who also found face the most common site of non-melanoma skin cancers. ${ }^{13,15}$ Face was mostly involved because of direct exposure to sun lights either due to occupational purposes or lack of awareness to use sun blocks while going out.

Out of 50 cases of BCC, 42 cases show positivity for BCC. This high (84\%) percentage of overexpression of p53 in BCC supports the interpretation that $\mathrm{p} 53$ is frequently mutated gene in case of BCC. These results are comparable with literature where overexpression of p53 protein in various studies has been reported in $42-92 \%$ cases of BCC. Stratigos et al has reported this immunoreactivity in $84.2 \%$ of BCCs. ${ }^{16}$ In $83 \%$ of BCCs of head and neck region, overexpression of p53 was detected immunohistochemically by Shea et al. ${ }^{17}$ Prevalence of p53 in $67.77 \%$ of BCCs has been observed by Khodaeiani $E$ et al. ${ }^{11}$ In Chinese population, low incidence of p53 mutation has been found in BCCs as compared to white people. Many mutations other than p53 have been found that are involved in pathogenesis of BCC in Chinese. ${ }^{18}$

These results explain that, there is significant role of p53 in pathogenesis of basal cell carcinomas. ${ }^{19,20}$

In literature, it is also reported that maximum mutations in p53 were ultraviolet specific i.e Cytosine $\rightarrow$ Thymine $(\mathrm{C} \rightarrow \mathrm{T})$ transition changes. Normal sun exposed skin also show UV specific changes in p53 gene. Thus, this observation provides evidence that UV light is the main cause of p53 mutation.

However, absence of p53 overexpression in remaining 8 cases explains that there are some other genes like PTCH1 which are involved in pathogenesis of basal cell carcinoma as explained by Madan et al. ${ }^{21}$

In present study, all cases of BCC were subtyped according to prominence of histopathological pattern. We found p53 immunoreactivity both in aggressive and non-aggressive variants of BCC. Also, there was no difference in staining pattern in between different types of BCC. Diffuse immunostaining pattern was seen both in aggressive and non-aggressive variants. Few studies reinforced our results. ${ }^{2}$ Moreover, there are some studies that contradict with our results. ${ }^{22}$ The contradictory results may be due to large sample size of their study, different technique or may be because of different factors involved in pathogenesis. Further studies to determine relationship of p53 with various histopathological variants of BCC need to be conducted.

Skin cancers are important cause of morbidity and mortality. Early detection is thus very important in cutaneous malignancies. Aggressive BCC subtypes have higher rates of recurrence and excision margin involvement. Targeted therapies based on knowledge of pathogenesis of tumor aids in deciding appropriate treatment strategies.

\section{CONCLUSION}

It was thus concluded that high prevalence of p53 protein in basal cell carcinoma explains its role in pathogenesis of basal cell carcinoma in 
form of mutation of p53 tumor inhibiting gene that is incompetent to perform its normal function of cell cycle arrest and apoptosis. The results have not revealed a substantial relationship between aggressive and non-aggressive subtypes of BCC at immunohistochemical level in terms of p53 expression and staining intensities.

\section{LIMITATIONS}

The main limitation of our study was limited number of cases. However, our study demonstrates that immunohistochemistry is a useful as well as cost effective technique for initial evaluation of gene mutation.

\section{CONFLICT OF INTEREST}

This study has no conflict of interest to declare by any author.

Copyright@ 09 July, 2019.

\section{REFERENCES}

1. Ahmed A, Alam MB, Khan W, Badar A, Shah SH. Frequency and characteristics of skin cancers diagnosed at Ayub Medical College, Abbotabad Pakistan from 1995-2003. J Ayub Med Coll Abbottabad. 2007; 19(4): 3-6.

2. Esmaeili R, Khorasani MS, Monsef A. Immunohistochemical expression of P53 and Ki-67 in different histopathological variants of basal cell carcinoma. Middle East Journal of Cancer 2015; 6(1): 29-34.

3. Rosai J. Skin. In Rosai J. Rosai and ackerman's surgical pathology. 10th ed. New Delhi: MosbyElsevier; 2011. 98-236.

4. Nedved D, Tonkovic-Capin V, Hunt E, Zaidi N, Kucenic MJ, Graves JJ, et al. Diagnostic concordance rates in the subtyping of basal cell carcinoma by different dermatopathologists. J Cutan Pathol. 2014; 41(1): 9-13.

5. Nakayama M, Tabuchi K, Nakamura Y, Hara A. Basal cell carcinoma of the head and neck. J Skin Cancer. 2011; 2011: 496910.

6. English DR, Armstrong BK, Kricker A, Winter MG, Heenan PJ, Randell PL. Case-control study of sun exposure and squamous cell carcinoma of the skin. Int J Cancer. 1998; 77(3): 347-53.

7. Gllagher RP, Lee TK, Bajdik CD, Borugian M. Ultraviolet radiation. Chronic Dis Can. 2010; 29(Suppl 1): 51-68.
8. Berhane T, Halliday GM, Cooke B, Barnetson RS. Inflammation is associated with progression of actinic keratoses to squamous cell carcinomas in humans. Br J Dermatol. 2002; 146(5): 810-5.

9. Neto PD, Alchorne M, Michalany N, Abreu M, Borra $R$. Reduced P53 staining in actinic keratosis is associated with squamous cell carcinoma: A preliminary study. Indian J Dermatol. 2013; 58(4): 325.

10. Batinac T, Zamolo G, Jonjić N, Gruber F, Petrovecki M. P53 protein expression and cell proliferation in non-neoplastic and neoplastic proliferative skin diseases. Tumori. 2004; 90(1): 120-7.

11. Khodaeiani E, Fakhrjou A, Amirnia M, BabaeiNezhad S, Taghvamanesh F, Razzagh-Karimi E, et al. Immunohistochemical evaluation of p53 and Ki67 expression in skin epithelial tumors. Indian $\mathrm{J}$ Dermatol. 2013; 58(3): 181-7.

12. Soomro FR, Bajaj DR, Pathan GM, Abbasi P, Hussain J, Abbasi SA. Cutaneous malignant tumors: A profile of ten years at LINAR, Larkana, Pakistan. JPAD. 2010; 20: 133-6.

13. Paracha MM, Shah AA, Irfanullah, Khan MA, Khan SA. Pattern of skin malignancies in patients presenting to dermatology deptartment Hayatabad Medical Complex Peshawar. J Postgrad Med. 2014; 28(1): 5861.

14. Chinem VP, Miot HA. Epidemiology of basal cell carcinoma. An Bras Dermatol. 2011; 86(2): 292-305.

15. Laishram RS, Banerjee A, Punyabati P, Sharma LD. Pattern of skin malignancies in Manipur, India: A 5year histopathological review. JPAD. 2010; 20: 12832.

16. Stratigos AJ, Kapranos N, Petrakou E, Anastasiadou A, Pagouni A, Christofidou E, et al. Immunophenotypic analysis of the p53 gene in non-melanoma skin cancer and correlation with apoptosis and cell proliferation. J Eur Acad Dermatol Venereol. 2005; 19(2): 180-6.

17. Shea CR, McNutt NS, Volkenandt M, Lugo J, Prioleau PG, Albino AP. Overexpression of p53 protein in basal cell carcinomas of human skin. Am J Pathol. 1992; 141(1): 25-9.

18. Wang YM, Huang YS, Ma ZH, Bu DF, Wang Y, Tu P, et al. Frequency and features of TP53 mutation in $\mathbf{3 0}$ Chinese patients with sporadic basal cell carcinoma. Clin Exp Dermatol. 2014; 39(7): 829-34.

19. Roewert-Huber J, Lange-Asschenfeldt B, Stockfleth $\mathrm{E}$, Kerl H. Epidemiology and aetiology of basal cell carcinoma. Br J Dermatol. 2007; 157(Suppl 2): 47-51. 
20. Donovan J. Review of the hair follicle origin hypothesis for basal cell carcinoma. Dermatol Surg. 2009; 35(9): 1311-23.

21. Madan V, Hoban P, Strange RC, Fryer AA, Lear JT. Genetics and risk factors for basal cell carcinoma. Br J Dermatol. 2006; 154(Suppl 1): 5-7.
22. Ansarin $H$, Daliri M, Soltani-Arabshahi R. Expression of P53 in aggressive and non-aggressive histologic variants of basal cell carcinoma. Eur J Dermatol. 2006; 16(5): 543-7.

\section{AUTHORSHIP AND CONTRIBUTION DECLARATION}

\begin{tabular}{|c|l|l|l|}
\hline Sr. \# & Author-s Full Name & \multicolumn{1}{|c|}{$\begin{array}{c}\text { Contribution to the paper } \\
1\end{array}$} & $\begin{array}{l}\text { Saira Javeed } \\
\text { Principal Author, Data collection, } \\
\text { Result analysis and discussion, } \\
\text { Corresponding Author. } \\
\text { Reviewer }\end{array}$ \\
\hline 3 & Ashok Kumar & Iram Asrar & Reviewer
\end{tabular}

